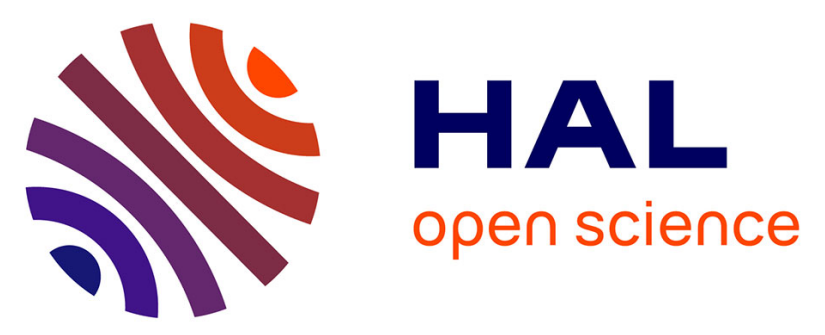

\title{
3D Anode Microbial Fuel Cell Characterization and Monitoring Coupling X-Ray Tomography and Electrochemical Impedance Spectroscopy
}

Justine Papillon, Benoît Ter-Ovanessian, Olivier Ondel, Jérôme Adrien, Éric Maire

\section{To cite this version:}

Justine Papillon, Benoît Ter-Ovanessian, Olivier Ondel, Jérôme Adrien, Éric Maire. 3D Anode Microbial Fuel Cell Characterization and Monitoring Coupling X-Ray Tomography and Electrochemical Impedance Spectroscopy. Journal of The Electrochemical Society, 2021, 168 (5), pp.054513. 10.1149/1945-7111/abfcdc . hal-03486802

\section{HAL Id: hal-03486802 https://hal.science/hal-03486802}

Submitted on 17 Dec 2021

HAL is a multi-disciplinary open access archive for the deposit and dissemination of scientific research documents, whether they are published or not. The documents may come from teaching and research institutions in France or abroad, or from public or private research centers.
L'archive ouverte pluridisciplinaire HAL, est destinée au dépôt et à la diffusion de documents scientifiques de niveau recherche, publiés ou non, émanant des établissements d'enseignement et de recherche français ou étrangers, des laboratoires publics ou privés. 


\section{D anode Microbial Fuel Cell characterization and monitoring coupling X-Ray tomography and Electrochemical Impedance Spectroscopy}

Justine PAPILLON*a, Benoît TER-OVANESSIAN ${ }^{\mathrm{a}}$, Olivier ONDEL ${ }^{\mathrm{b}}$, Jérôme ADRIEN ${ }^{a}$, Éric MAIRE ${ }^{a}$

${ }^{a}$ Univ. Lyon - INSA Lyon - MATEIS, UMR CNRS 5510, F-69100 Villeurbanne, France

${ }^{b}$ Univ. Lyon, Université Claude Bernard Lyon 1, École Centrale de Lyon, INSA Lyon, CNRS, Ampère, F-69621, Villeurbanne, France

\section{Abstract}

Entangled stainless steel single wire was used as a promising 3D anode for Microbial Fuel Cells (MFCs). Two complementary techniques were coupled to precisely characterize the anode structure and activity: X-Ray Computed Tomography (XRCT) and Electrochemical Impedance Spectroscopy (EIS). XRCT provides an acurate estimation of the pore distribution and size while EIS allows to check and monitor the electrochemical activity. Electrochemical measurements were performed with activated sludges and synthetic medium at an imposed potential of $-0.2 \mathrm{~V}$ vs $\mathrm{Ag} / \mathrm{AgCl}$ in a single chamber $\mathrm{MFC}$. Modified Transmission Line Model was used to follow the evolution of the anode in both media including the formation and the growth on the biofilm. Keywords: Microbial fuel cells, 3D anode, Stainless steel anode, X-Ray tomography, Electrochemical Impedance Spectroscopy.

\section{*Corresponding author:}

Justine PAPILLON

Tel: +33472436381 

Laboratoire MATEIS

25, avenue Jean Capelle

Bâtiment Saint Exupéry

69621 Villeurbanne Cedex

30

FRANCE

\section{Introduction}

The environment that surrounds us contains a multitude of potential sources of energy, sometimes even unsuspected. In the current environmental context, a lot of research is being conducted today in the field of alternative energies (wind, solar, hydraulic, geothermal,...) aiming at a massive production of electricity. But a myriad of solutions on a much smaller scale are also being developed. They could make it possible to convert into electricity even the smallest amounts of energy available in the surrounding environment or extracted from human activity: these are named energy harvesting solutions. Microbial Fuel Cells (MFCs) are a perfect illustration of this type of solutions.

In bioelectrochemical systems such as MFCs, a respiration mechanism converts part of the energy contained in various biodegradable substrates into electricity. The anode material can be used as a final electron acceptor

45 by the exo-electrogenic micro-organisms that will grow on its surface [1].

Given that it is an energy harvesting solution, the challenges are obviously to obtain the best possible power densities but with the lowest possible 
cost, ensuring the good stability over time of the material and its easy use at industrial scales. These essential compromises led us to use stainless steel anodes which appears to be a promising material because, in addition to the criteria previously mentioned, it exhibits a high electrical conductivity, high mechanical properties and easy formability [2] [3] [4]. In order to improve the performance of this electrode, a simple and effective method was also employed: the architecturization of the electrodes [5] [6] [7]. The use of 3D anodes, like entangled single wire used in this study, permits an increase in the specific surface area (in $\mathrm{m}^{2} / \mathrm{m}^{3}$ ) of the electrode and thus provides the micro-organisms a larger surface area for growth. The intrinsic dimensions must be optimized to promote mass transport within the entire developed surface [7]. The size of the porosities is a particularly important parameter to control. Using anodes with too small pores would lead to clogging problems, conversely, using anodes with too large pores would reduce the active surface of the electrode and in both cases this would lead to a decrease in performance.

3D characterization of architectural materials is particularly complex. XRay Computed Tomography (XRCT) is one of the few techniques that is particularly relevant to tackle this challenge. This non-destructive technique indeed allows to reconstruct a volumetric image of the material from $2 \mathrm{D}$ radiographies taken at different viewing angles. Now very commonly used in material science, this technique is also beginning to make its mark in the 70 field of batteries and fuel cells [8] [9] [10] [11] [12] [13] [14] [15] where it provides valuable information on the morphology of electrode materials. In this paper, XRCT will be used to determine the pore size within the highly 
porous anodes employed.

The use of 3D electrodes for electrochemical devices increases the active De Levie impedance which considers the reactivity inside a cylindrical pore, were proposed [19]. The Transmission Line Model (TLM) which is directly related to the De Levie approach was mainly used to study porous electrodes in the case of both faradaic and non faradaic processes [17] [20] [21] [22] [23] 95 [24]. In different works, TLM was modified and adapted to the complexity of the electrode, and the literature is full of different equation forms [17] [22] [24]. Generally, numerous geometrical parameters, as depth of pore, diam- 
eter of pore or tortuosity need to be fitted or postulated in addition to the electrochemical parameters. By only performing Electrochemical Impedance Spectroscopy (EIS) with numerous unknown parameters, it is sometimes a real issue to accurately assess all the parameters and thus characterize electrochemically such electrode. The use of other characterization techniques (such as XRCT in this study) can provide useful information, complementary to EIS.

This paper shows the interest of XRCT / EIS linkage in the field of bioelectrochemical systems. Tomography data have been coupled with EIS measurements to develop models integrating the dimensional characteristics of architected electrodes and provide considerable and in-depth information on the metabolism of exo-electrogenic bacteria, electron transfer mechanisms, material and surface properties of the electrodes. This is essential for understanding the processes involved in electricity generation and their limiting factors in order to improve the energy efficiency of MFCs.

\section{Experimental}

\subsection{Fabrication of anodes}

115 The anodes used in this study were made from an entangled 304L stainless steel monofilament. They were shaped by oedometric compression: the monofilament was first entangled manually to obtain a homogeneous ball, and then, was placed in a matrix where a piston was used to compress it (Figure 1) [25]. 


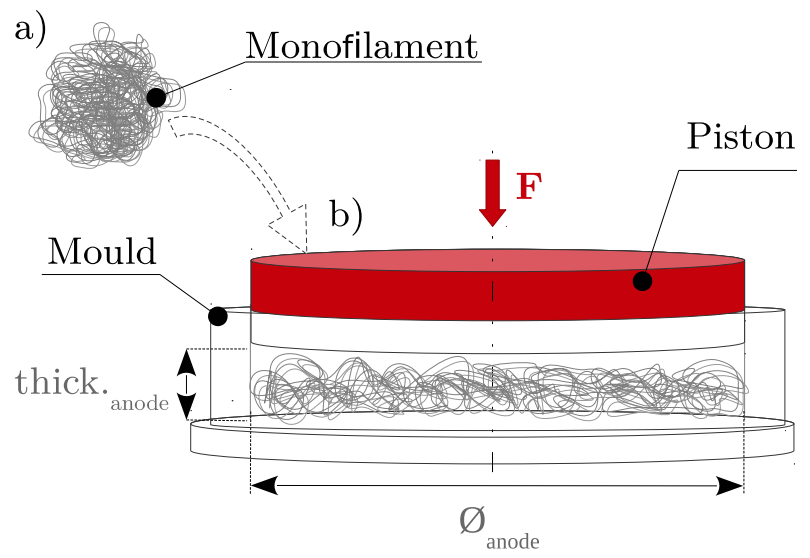

Figure 1: Anode shaping: a) manual preforming then b) compression in a mould.

120

\subsection{Morphological characterization of anode}

The thickness of the anode, $T h_{\text {anode }}$, was directly controlled by the displacement applied on the piston. The diameter of the anode, $\varnothing_{\text {anode }}$ was equal to the diameter of the mould used. The projected surface, $S_{\text {projected }}$, could be determined by the formula:

$$
S_{\text {projected }}=\pi \cdot\left(\frac{\varnothing_{\text {anode }}}{2}\right)^{2}
$$

The diameter of the wire used, $\varnothing_{\text {wire }}$, as well as its length, $L_{\text {wire }}$, being perfectly known, the anode developed surface, $S_{\text {developped }}$, also called active surface, was easily calculated as:

$$
S_{\text {developped }}=2 \pi \cdot\left(\frac{\varnothing_{\text {wire }}}{2}\right) \cdot L_{\text {wire }}
$$

The volume fraction of wire in the anode, $V_{f}$, is also simple to determine with the formula :

$$
V_{f}=\frac{\mathrm{L}_{\text {wire }} \cdot \varnothing_{\text {wire }}^{2}}{\mathrm{Th}_{\text {anode }} \cdot \varnothing_{\text {anode }}^{2}}
$$



matrix.

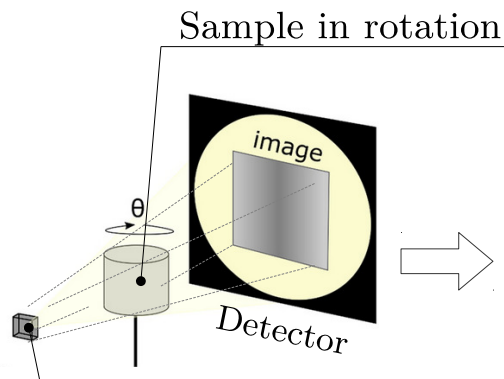

X-ray source

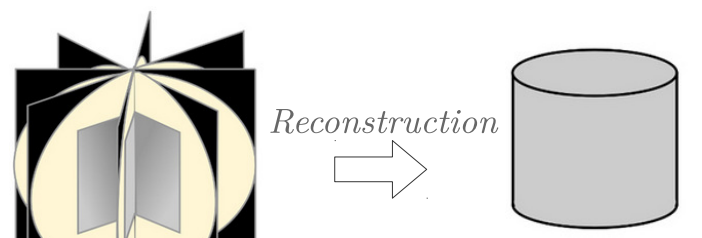

$3 \mathrm{D}$

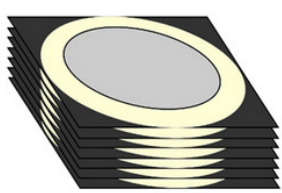

2D Slices

Figure 2: Principle of X-ray tomography [27]

The acquisitions were carried out with a polychromatic source operating at a voltage of $120 \mathrm{kV}$ and a voxel size of $30 \mu \mathrm{m}^{3}$. The reconstructions were obtained using the commercial software supplied with the tomograph.

The analysis of the X-ray tomography data was carried out using Fiji software [28]. The method used is summarised in Figure 3. The Computed To- 
mography (CT) volumes were first processed with a median filter to smooth the image and were then segmented. The pore size was next determined using a granulometry tool (Local Thickness plugin, [29]). This tool measures the size of the largest possible sphere located in each pixel of the pores. A histogram of the size distribution of the pores can then be plotted.

a)

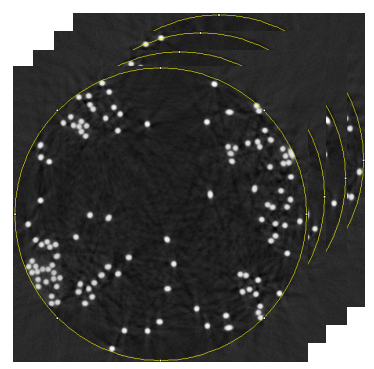

b)

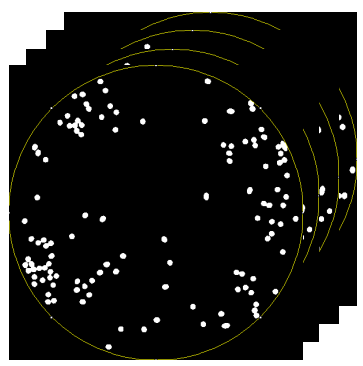

c)

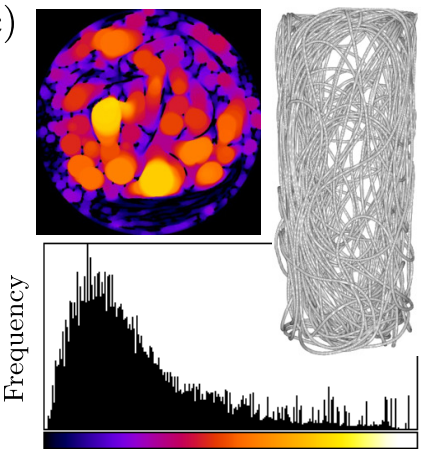

Pores diameter $[\mu \mathrm{m}]$

Figure 3: Principle of image analysis: a) volume just after reconstruction; b) threshold volume; c) examples of parameters available with X-ray tomography (3D rendering, pore size, ...).

For this 3D characterisation, the anodes used in tomography were manufactured identically to the anodes embedded in the MFC but with smaller dimensions. The tomograph used in this study did not allow imaging the anodes in their entirety because the absorption of X-rays was too high through them. Tests were carried out with different matrix diameters (15 and $40 \mathrm{~mm}$ ) and showed that this parameter had a very limited influence on the diameter of the pores formed within the entanglement. The results presented in this article refer to those obtained with $40 \mathrm{~mm}$ diameter anodes. Parameters that have an important influence on the pore size are rather the volume fraction 


\begin{tabular}{ll}
\hline Wire diameter, $\varnothing_{\text {wire }}$ & $280 \mu \mathrm{m}$ \\
\hline Wire length, $L_{\text {wire }}$ & $169 \mathrm{~m}$ \\
\hline Anode diameter, $\varnothing_{\text {anode }}$ & $115 \mathrm{~mm}$ \\
\hline Anode thickness, $T h_{\text {anode }}$ & $10 \mathrm{~mm}$ \\
\hline Volume fraction, $V_{f}$ & $10 \%$ \\
\hline Projected surface, $S_{\text {projected }}$ & $104 \mathrm{~cm}^{2}$ \\
\hline Active surface, $S_{\text {dvelopped }}$ & $1480 \mathrm{~cm}^{2}$ \\
\hline
\end{tabular}

Table 1: Anode parameters.

of wire within the anode and the diameter of the monofilament used. We therefore assume in the rest of the paper that the pore diameters measured in tomography are representative of those found within the anodes.

Table 1 summarises the architectural parameters of the anodes tested in this study.

\subsection{Experimental electrochemical protocol}

The stainless steel wire entangled anodes were embedded in single compartment MFCs with an electrolyte volume of $1100 \mathrm{~mL}$. These reactors were equipped with air-cathodes manually manufactured according to the process described by Middaugh [30], with a layer of platinum-based catalyst

$170\left(0.5 \mathrm{mg} . \mathrm{L}^{-1}\right)$ applied on the side in contact with the electrolyte in order to improve the oxygen reduction reaction. The air-cathode had a developed surface area of $95 \mathrm{~cm}^{2}$. A reference electrode $(\mathrm{Ag} / \mathrm{AgCl})$ was placed at an equal distance of $2 \mathrm{~cm}$ from the two MFC electrodes. The MFCs were inoculated with two batches of activated sludge collected at the Feyssine wastewater treatment plant (Villeurbanne, 69100 FRANCE). After 10 days of inocula- 
tion, the activated sludge was replaced by a synthetic medium doped with acetate $\left(1 g \cdot L^{-1}\right)$. This medium was then regularly renewed as soon as substrate shortages were observed with sudden drops in performance. Tests were carried out at room temperature and in the dark to prevent algae formation. The ionic conductivity of the synthetic medium used was $3.2 \mathrm{mS}_{\mathrm{cm}} \mathrm{cm}^{-1}$ and the $\mathrm{pH}$ was 7.2. During the entire test (inoculation and monitoring), a potential of $-0.2 \mathrm{~V}$ vs $\mathrm{Ag} / \mathrm{AgCl}$ was imposed at the anode. The choice of this potential is consistent with literature [31] and will be discussed according to the polarization curve.

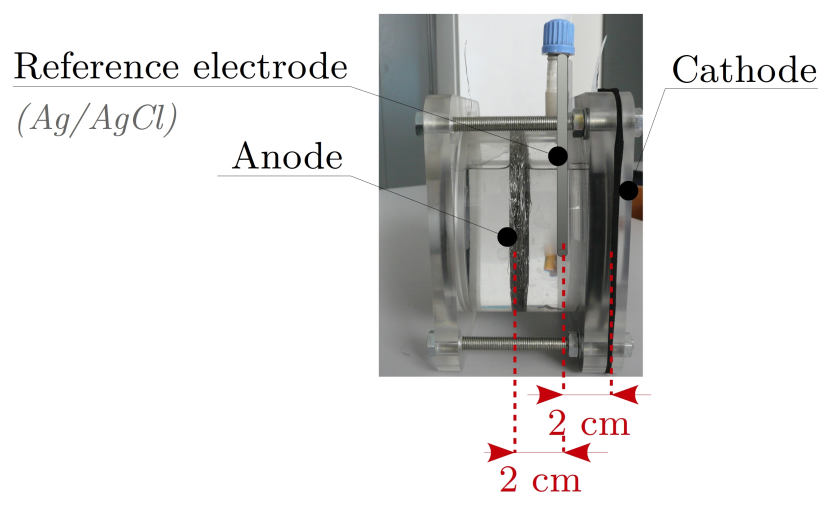

Figure 4: Experimental set-up. 3-electrode assembly: working electrode $=$ anode, counter electrode $=$ air-cathode and reference electrode $=\mathrm{Ag} / \mathrm{AgCl}$ electrode.

\subsection{Electrochemical characterization of the studied anode}

The electrochemical measurements were carried out using an Interface 1000 potentiostat from Gamry instrument. The previously described single compartment $\mathrm{MFC}$ outfitted with an $\mathrm{Ag} / \mathrm{AgCl}$ reference electrode was used as 3-electrode set-up. The stainless steel wire entangled anode and 
the air-cathode were considered working electrode and counter electrode, respectively. Reproducibility of the measurement was validated through three different measurement campaigns. Only representative results were reported in the presented work.

\subsubsection{Polarisation curve}

After 16 days of operation (at an imposed potential of $-0.2 \mathrm{~V}$ vs $\mathrm{Ag} / \mathrm{AgCl}$ ), the electrochemical behaviour was determined using linear scanning voltametry. The potential applied to the anode varied linearly from -0.65 to $+0.2 \mathrm{~V}$ vs $\mathrm{Ag} / \mathrm{AgCl}$ with a scanning rate of $1 \mathrm{mV} . \mathrm{s}^{-1}$.

\subsubsection{Chronoamperometry and Electrochemical Impedance Spectroscopy}

For the duration of the test, a potential of $-0.2 \mathrm{~V}$ vs $\mathrm{Ag} / \mathrm{AgCl}$ was imposed at the anode and the current was recorded every $300 \mathrm{~s}$. EIS tests in potentiostatic mode were carried out every 24 hours at the same potential to describe the interface state and reactivity. Impedance measurements were performed over the frequency ranging from $100 \mathrm{kHz}$ to $1 \mathrm{mHz}$, with 9 points 205 per decade and a sine wave of $10 \mathrm{mV}$ amplitude signal. For the sake of clarity, only the impedance diagrams obtained at $24 \mathrm{~h}, 72 \mathrm{~h}$ and $120 \mathrm{~h}$ for the first and second inoculation periods (activated sludge 1 and 2) and for testing period (synthetic medium) are shown in the present manuscript.

\section{Theoretical approach}

Impedance diagrams were analysed using enhanced graphical representation and analysis and a non-commercial fitting software developed at the LISE CNRS, Paris. As the entangled wire anode could be considered a 
macroporous electrode, a model derived from the transmission line model (TLM) was used [17] [24]. In the present case, charge transfer occurs at the electrode surface in presence of the biofilm. Consequently, we have to consider the following expression of the impedance described for cylindrical pores by use of the transmission line model:

$$
Z_{\text {anode }}=\sqrt{\frac{\mathrm{R}_{\mathrm{ion}, \mathrm{L}} \cdot \mathrm{R}_{\mathrm{ct}, \mathrm{A}}}{\left(1+\mathrm{j} \omega \mathrm{R}_{\mathrm{ct}, \mathrm{A}} \mathrm{C}_{\mathrm{dl}, \mathrm{A}}\right) \cdot 2 \pi r}} \cdot \operatorname{coth}\left(\sqrt{\frac{\mathrm{R}_{\mathrm{ion}, \mathrm{L}}\left(1+\mathrm{j} \omega \mathrm{R}_{\mathrm{ct}, \mathrm{A}} \mathrm{C}_{\mathrm{dl}, \mathrm{A}}\right) \cdot 2 \pi \mathrm{r}}{\mathrm{R}_{\mathrm{ct}}}} \cdot L\right)
$$

Where $\omega$ is the pulsation $\left(s^{-1}\right), R_{i o n, L}$ is the ionic resistance per unit pore length $\left(\Omega . c m^{-1}\right), R_{c t, A}$ is the charge transfer resistance per unit surface area $\left(\Omega . c m^{2}\right), C_{d l, A}$ is the electric double layer capacitance per unit surface area $\left(F . \mathrm{cm}^{-2}\right)$ and $\mathrm{r}$ and $\mathrm{L}$ are the average radius of the pores and the total thickness of the electrode. In the present work, the total thickness was fixed to $1 \mathrm{~cm}$ (geometrically determined) and the average radius was determined by X-ray tomography. $R_{i o n, L}$ is a characteristic parameter that expresses the mobility of charged species inside the electrode mesh. In this equation, the electrochemical reaction is assumed to occur similarly on the overall active surface. Indeed, $R_{c t, A}$ and $C_{d l, A}$ should be constant along the wall of the pores. With the studied electrode, it is not the case for, at least, two reasons: the electrode is not fully recovered by the bacterial film (even after inoculation) and some bacterial clusters are reported at wire crossing; the electrode is made of stainless steel, a passive material, for which a constant phase element (CPE) behavior is generally observed at high frequency rather than a pure capacitance. For these reasons, the capacitance used in equation 4 is replaced by the impedance of a CPE: 


$$
Z_{C P E}=\frac{1}{\mathrm{Q}(\mathrm{j} \omega)^{\alpha}}
$$
impedance is then calculated by (eq.6):

$Z_{\text {anode }}=\sqrt{\frac{\mathrm{R}_{\mathrm{ion}, \mathrm{L}} \cdot \mathrm{R}_{\mathrm{ct}, \mathrm{A}}}{\left(1+(\mathrm{j} \omega)^{\alpha} \mathrm{R}_{\mathrm{ct}, \mathrm{A}} \mathrm{Q}_{\mathrm{dl}, \mathrm{A}}\right) \cdot 2 \pi r}} \cdot \operatorname{coth}\left(\sqrt{\frac{\mathrm{R}_{\mathrm{ion}, \mathrm{L}}\left(1+(\mathrm{j} \omega)^{\alpha} \mathrm{R}_{\mathrm{ct}, \mathrm{A}} \mathrm{Q}_{\mathrm{dl}, \mathrm{A}}\right) \cdot 2 \pi \mathrm{r}}{\mathrm{R}_{\mathrm{ct}, \mathrm{A}}}} \cdot L\right)$

The overall impedance measured (in $\Omega$ ) may be calculated by:

$$
Z=R_{\text {solution }}+Z_{\text {anode }}
$$

Where $R_{\text {solution }}$ is the resistance of the solution (depending on the distance between the anode and the reference electrode). According to Eq. 7, the limiting values of the real and imaginary parts, Z' and Z" respectively, as the frequency tend to 0 may be written as follows:

$$
\lim _{\omega \rightarrow 0} Z^{\prime}=R_{\text {solution }}+\frac{R_{\text {ion }}}{3}+R_{c t} \quad \text { and } \quad \lim _{\omega \rightarrow 0} Z^{\prime \prime}=0
$$


Where $R_{i o n}$ is the ionic resistance in pores $\left(R_{i o n}=R_{i o n, L} . L\right.$, in $\left.\Omega\right)$ and $R_{c t}$ is the total charge transfer resistance $\left(R_{c t}=R_{c t, A} / 2 \pi \mathrm{rL}\right.$, in $\left.\Omega\right)$. In most of the cases, these parameters can be determined graphically on Nyquist diagrams [24]. This graphical determination is useful to discuss the results obtained by the fitting software. In the present study, it is worth mentioning that almost all the parameters used to describe the reactivity of the interface could be estimated by another way than by software fitting procedure. Geometrical parameters were determined by physical techniques as XRCT while numerous electrochemical parameters were assessed by different graphical representations of the impedance data. This methodology insures the consistency of the fitting and the physical meaning of the parameters.

\section{Results and Discussion}

\subsection{Determination of pore size}

The pores within the entanglements are quite heterogeneous in size. An important edge effect can be observed within these materials: the wire tends to press against the walls of the mould when the entanglements are shaped and therefore the pores found in the central part of the anode are much larger than those at the edge. Figure 5 shows the pore size distribution measured in the studied anode. The dispersion of the pore size reach a maximum around 1-1.5 $\mathrm{mm}$ with an average measured pore diameter equal to $2.02 \mathrm{~mm}$. This indicates that the anode could be considered as a mesomacroporous electrode. This finding has to be taken into account to model the electrochemical behaviour of the electrode. A pore radius around $1 \mathrm{~mm}$ will be used for the analysis of the impedance diagrams. 


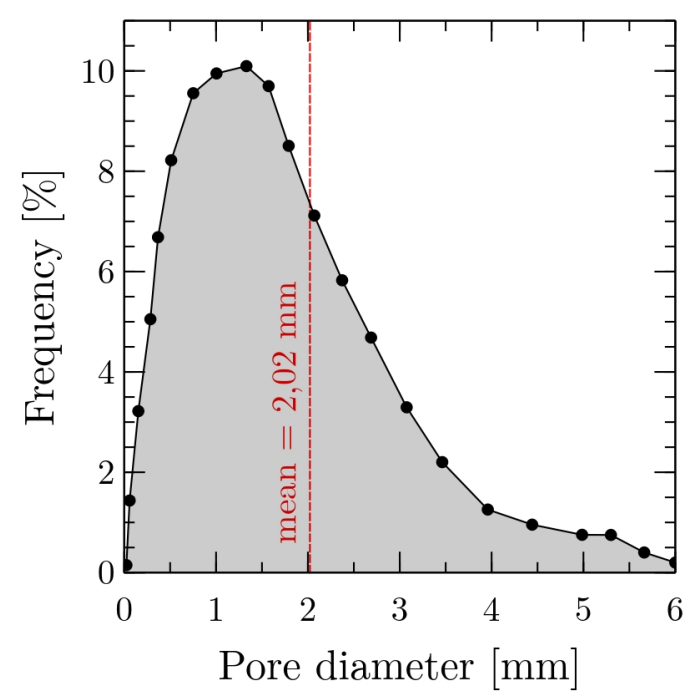

Figure 5: Pore size distribution within the anodes.

\subsection{Electrochemical characterization}

\subsubsection{Polarisation curve}

To determine the most suitable working potential to be applied to the anode, a linear sweep voltametry test was carried out. The polarizarion curve shown in Figure 6 exhibits the common trend of anode. The zero current potential was $-0.47 \mathrm{~V}$. The quasi-linear shape of the curve from $-0.47 \mathrm{~V}$ to $0.098 \mathrm{~V}$ vs $\mathrm{Ag} / \mathrm{AgCl}$ seems to indicate an ohmic behaviour of the electrode.

The potential value of $-0.2 \mathrm{~V}$ vs. $\mathrm{Ag} / \mathrm{AgCl}$ is included in this electrochemical regime and appears to be an interesting compromise allowing a high generated current and preventing other anodic reaction contributions or depletion of reactive species. Moreover, this choice is consistent with the work of Aelterman [31], who showed that a potential of $-0.2 \mathrm{~V}$ vs. $\mathrm{Ag} / \mathrm{AgCl}$ was optimal because it allowed faster biofilm growth, was more electrochem- 
ically active and resulted in higher electricity generation.

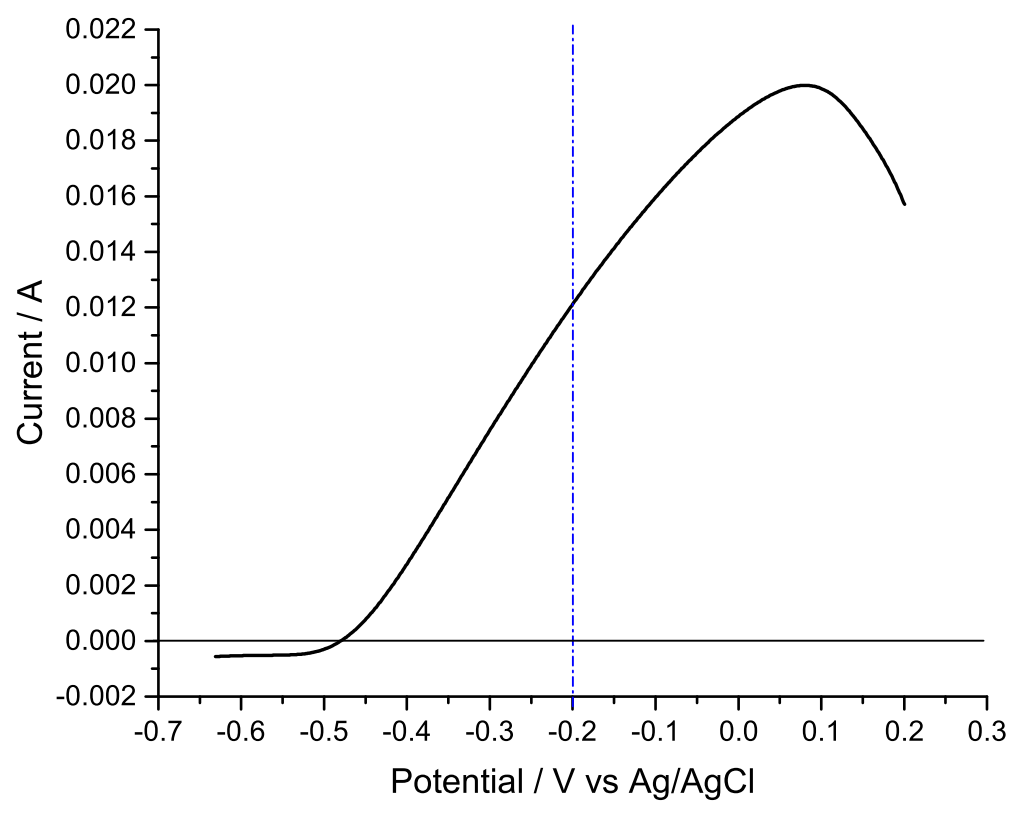

Figure 6: Anode polarisation curve.

\subsubsection{Anode current evolution over time}

The results of chronoamperometric measurements carried out with an applied potential of $-0.2 \mathrm{~V}$ vs $\mathrm{Ag} / \mathrm{AgCl}$ are shown in Figure 7. During the first inoculation period, the current remains constant at a low value up to 72 h. After this latency period, The increase in current indicates that the biofilm 295 is nucleated but does not cover totally the anode or is not totally active. After $72 \mathrm{~h}$, the anodic biofilm begins to form on the surface of the anode and electron transfer between the micro-organisms and the anode material 
starts. After $96 \mathrm{~h}$, the current reaches a plateau at $2.4 \mathrm{~mA}$. Steady state is achieved. During the second inoculation, the latency phase is reduced. In fact, after $24 \mathrm{~h}$, the same plateau is reached. When the cell is supplied with the synthetic medium, a drop of current and a new latency period are observed. The biofilm needs time to accommodate to the new electrolyte. After $72 \mathrm{~h}$, the steady-state is then achieved and a current plateau at $15.1 \mathrm{~mA}$ is reached. Note that the change of the solution has an effect on the activity of the micro-organisms who need time to reach their optimal activity.

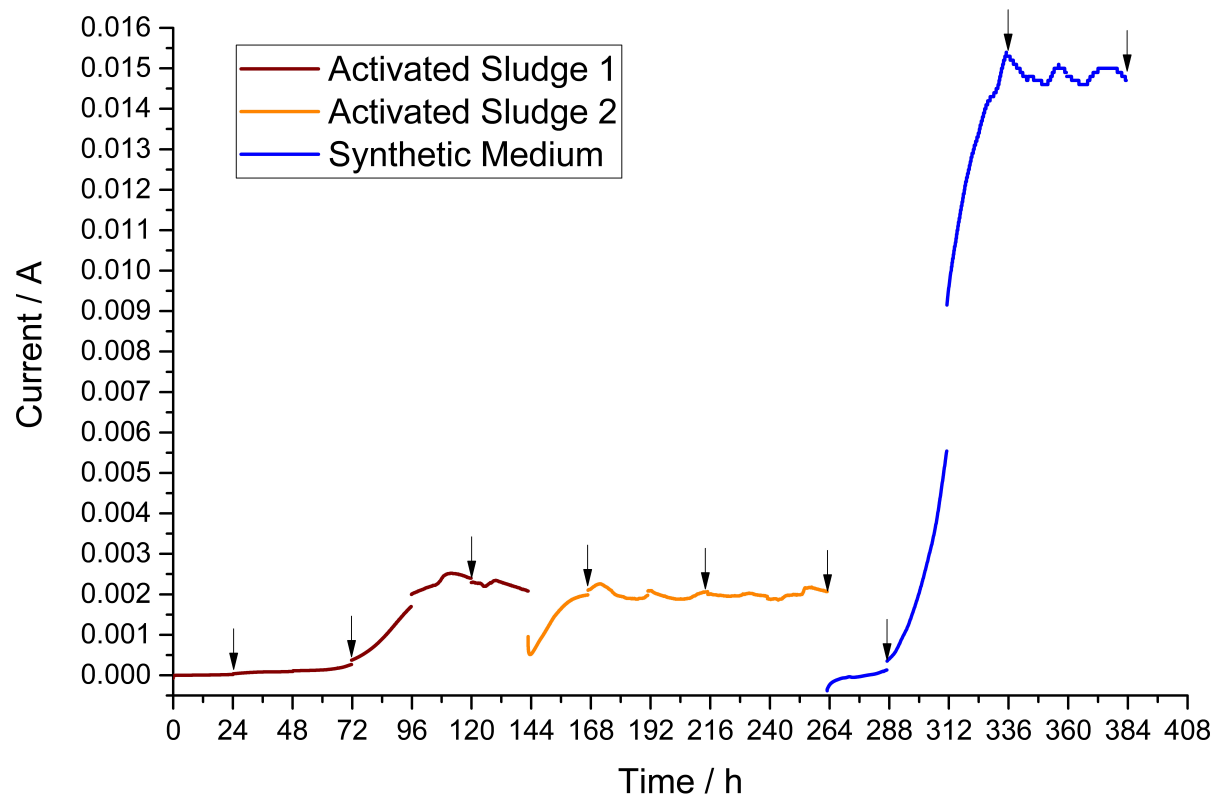

Figure 7: Anode current evolution over time. 
4.2.3. Evolution of the anode/electrolyte interface: Analysis of the EIS diagrams

Nyquist representations of the impedance data obtained at $24 \mathrm{~h}, 72 \mathrm{~h}$ and $120 \mathrm{~h}$ during inoculation 1, inoculation 2 and in service are plotted in Figure

8, 9, 10 respectively. Dashed lines display the results of the fitting using eq. 7. Experimental impedance diagrams and fitted curves are close, except at low frequencies, where the EIS signal is disturbed and not exploitable (loss of stationarity or causality). The fit is consistent with the experimental diagram.

( a )

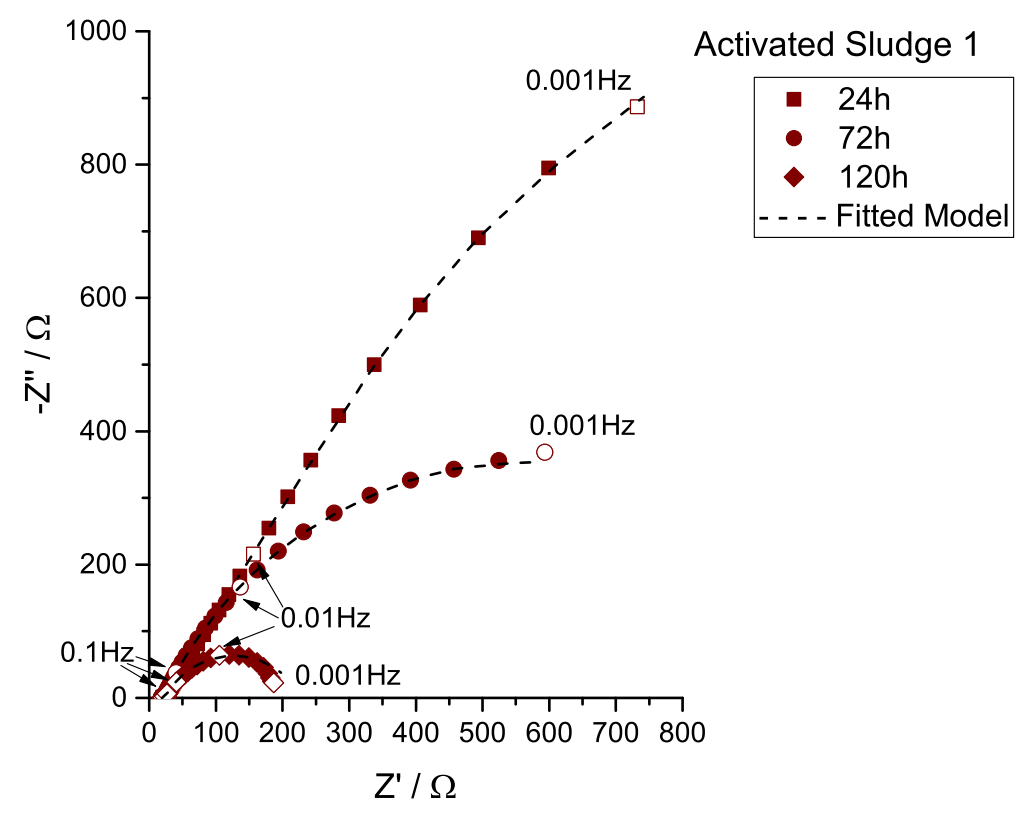

Figure 8: Nyquist representations of the impedance data obtained at $24 \mathrm{~h}, 72 \mathrm{~h}$ and 120 h during inoculation 1. 
(b)

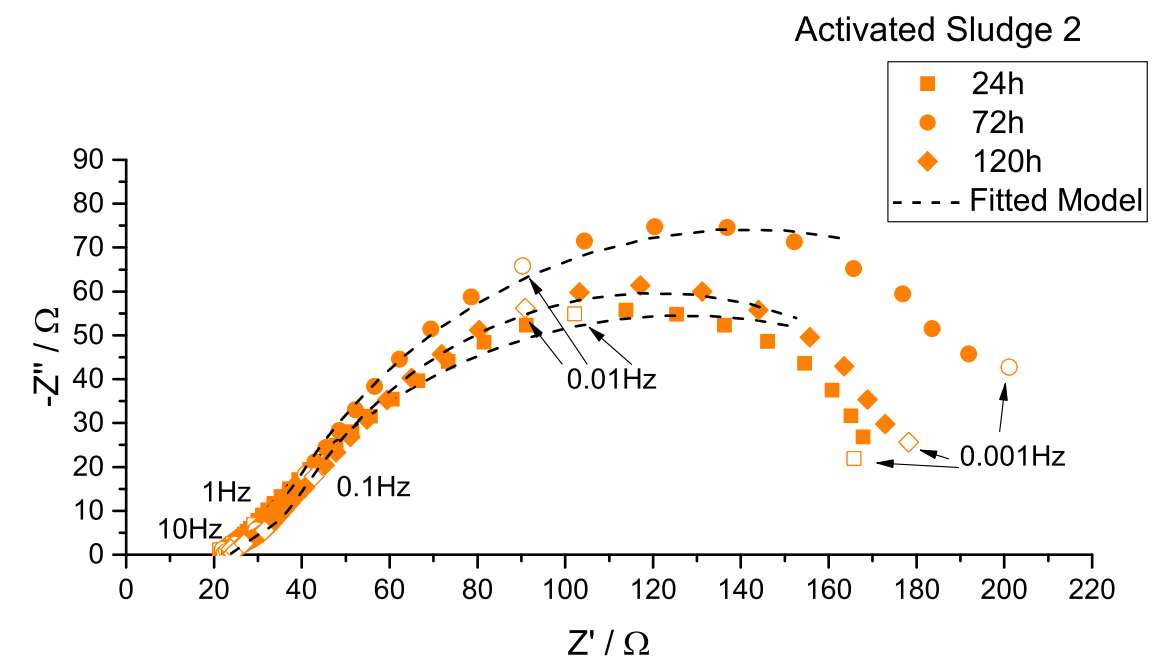

Figure 9: Nyquist representations of the impedance data obtained at $24 \mathrm{~h}, 72 \mathrm{~h}$ and 120 $\mathrm{h}$ during inoculation 2 .

For all the reported results, the impedance diagram is composed of three parts: the first part at high frequencies is related to the reference electrode or set-up artefact; then at high-middle frequencies (in a restricted frequency range), the impedance diagram reveals a linear tendency related to a diffussive behavior through the mesoporous structure and finally a depressed semicircle more or less defined, linked with the charge transfer at the electrode surface. In Fig 8, the size of the semicircle decreases with time suggesting that the electrode surface is modified and that charge transfer is promoted. In the case of the second inoculation (Fig 9), impedance diagrams are almost 


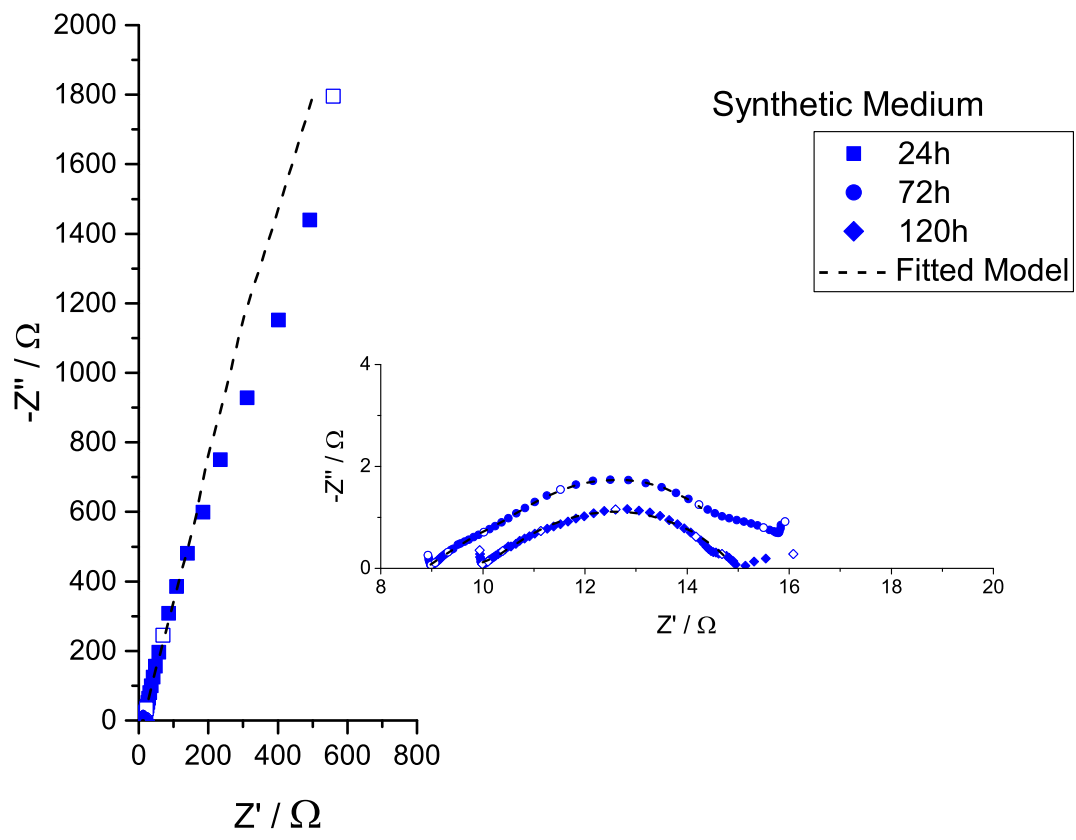

Figure 10: Nyquist representations of the impedance data obtained at $24 \mathrm{~h}, 72 \mathrm{~h}$ and 120 $\mathrm{h}$ in service.

the same. This finding proves that the stationarity is reached. The biofilm 325 is mature and stable. Finally, when the medium is changed (from activated sludge to synthetic medium), it is necessary to wait for the adaptation of the bioactivity before reaching again stability. Indeed after $24 \mathrm{~h}$, the impedance diagram highlights a capacitive behaviour, while for $72 \mathrm{~h}$ and $120 \mathrm{~h}$ the size of the semicircle is small indicating a small polarisation resistance for this system.

All the fitted parameters obtained by the adjustment of the impedance spectra are reported in Table 2. The calculated total charge transfer re- 
sistance $R_{c t}\left(R_{c t}=R_{c t, A} / 2 \pi \mathrm{rL}\right.$, in $\left.\Omega\right)$ and the total electric double layer capacitance $C_{d l}\left(C_{d l}=C_{d l, A} \times 2 \pi \mathrm{rL}\right.$, in $\left.F\right)$ are also reported in this table.

335 to the thickness of the electrode. Conversely, the average radius is a "free" fitted parameter. Then, it is worth mentioning that the obtained value is straightforwardly consistent with the value obtained by the X-ray tomography measurement. Moreover, the fact that it remains the same for all the 340 proposed: micro-organisms are embedded in the passive layer and act as a 
local short-circuit; passive film is broken down by the presence or the activity of the micro-organisms. Whatever the real phenomenon, the value of $R_{c t, A}$ indicates that the current is correctly collected by the electrode. During this first inoculation period, $R_{i o n, L}$ slightly increases suggesting a small slowdown of the ionic species transport through the electrode or a local depletion of nutriments due to micro-organisms consumption. It is also possible that for long time immersion with activated sludge, nutriments could sediment and limit the activity of the micro-organism. The slight increase of the double layer capacitance confirms the modification of the electrode/solution interface and the passive behavior of the stainless steel at the beginning of the test.

For the second inoculation period, steady state is reached $24 \mathrm{~h}$ after the renewal of the activated sludge. The value of $R_{c t, A}$ and $R_{i o n, L}$ are similar to the ones obtained at the end of the first inoculation. Besides, $R_{c t, A}$ remains constant and relatively low during all this second inoculation period. $R_{i o n, L}$ increases for the reasons mentioned above. $C_{d l, A}$ increases during this second period suggesting that even if the biofilm is formed and steady state is achieved, maturation of the biofilm still occurs.

When solution is changed and synthetic medium is used, the evolution of the current shown in Figure 7 points out that a latency period is again required to achieve functional steady-state. At $24 \mathrm{~h}, R_{c t, A}$ exhibits a high value related to the biological inactivity of the micro-organism caused by the solution change. This very high value seems to confirm that the passive film still exists at the surface of the electrode protecting it against corrosion. After $72 \mathrm{~h}, R_{c t, A}$ reaches a lower value which remains similar at $120 \mathrm{~h}$. 
The activity of the micro-organisms reaches its optimum for the considered applied potential. $R_{i o n, L}$ decreases with time indicating that the transport

385 mains constant after $72 \mathrm{~h}$ evidencing that steady state is achieved in terms of charge transfer, but also maturation and activity of the biofilm. At this stage, $R_{\text {solution }}, R_{\text {ion }}$ and $R_{c t}$ are in the same order of magnitude (few $\Omega$ ). This result clearly evidences that 3D entangled wire anodes do not provide the value of $R_{\text {solution }}$ is higher than the two others suggesting that the limitation for the anodic part of the fuel cell is rather related to the conductivity than to the charge transfer at the surface of the electrode [35].

\section{Conclusion}

Accurate characterization and monitoring of 3D anodes by coupling XRay tomography and EIS were presented in this paper.

X-ray tomography, although new in the field of MFCs, proved to be a very relevant technique to precisely characterize the morphology of 3D anodes. In this study, it was used to show the non-homogeneous distribution of porosities within a stainless steel entanglement with larger pore sizes in the center of the material. The pore size distribution shows a maximum around $1-1.5 \mathrm{~mm}$, a meso-macrovalue that was retained for impedance analysis.

Electrochemical measurements performed in a single chamber MFC for activated sludge and synthetic medium demonstrates: - At least 96h is required in activated sludge to achieve the stability of current for an applied potential of $-0.2 \mathrm{~V}$ vs $\mathrm{Ag} / \mathrm{AgCl}$. After this delay, the biofilm is formed and 
maintains an electrochemical activity. - A current of $2.4 \mathrm{~mA}$ was obtained in activated sludge while for synthetic medium the maximum current was $15.1 \mathrm{~mA}$. The use of X-ray tomography results and enhanced graphical determination of impedance parameters allow in-depth characterization of the evolution of the surface of the anode using modified TLM. The high polarization resistance of the anode due to passive film decreases significantly during the formation and growth of the biofilm, even if the latter do not fully cover the electrode (micro-organisms cluster). Moreover, EIS results indicate that the main limitation of this single MFC chamber is the resistance of the electrolyte which is 2 times higher than the charge transfer resistance. Optimization of the distance between electrodes or design of the cell are then required improvements for the development of the MFC technology.

\section{Data availability}

The raw/processed data required to reproduce these findings cannot be shared at this time because of technical or time limitations.

\section{Acknowledgements}

This study was supported by Rhône-Alpes Region (ARC Energy).

\section{References}

\section{References}

[1] D.R. Bond and D.R. Lovley. Electricity production by geobacter sulfurreducens attached to electrodes. Applied and environnemental microbiology, 69(3):1548-1555, 2003. 
[2] C. Dumas, A. Mollica, D. Féron, R. Basseguy, L. Etcheverry, and

A. Bergel. Checking graphite and stainless anodes with an experimental model of marine microbial fuel cell. Bioresource Technology, 99:88878894, 2008.

[3] B. Erable and A. Bergel. First air-tolerant effective stainless steel microbial anode obtained from a natural marine biofilm. Bioresource Technology, 100:3302-3307, 2009.

[4] D. Pocaznoi, A. Calmet, L. Etcheverry, B. Erable, and A. Bergel. Stainless steel is a promising electrode material for anodes of microbial fuel cells. Energy and Environmental Science, 5(11):9645-9652, 2012.

[5] S.F Ketep, A Bergel, A. Calmet, and B. Erable. Stainless steel foam pushes the current provided by microbial bioanodes for bioelectrochemical systems. Energy \& Environmental Science, 6(5):1633-1637, 2014.

[6] J.M. Sonawane, S.A. Patil, P.C. Ghosh, and S.B. Adeloju. Low-cost stainless-steel wool anodes modified with polyaniline and polypyrrole for high-performance microbial fuel cells. Journal of Power Sources, 379:103-114, 2018.

[7] J. Hou, Z. Liu, S. Yang, and Y. Zhou. Three-dimensional macroporous anodes based on stainless steel fiber felt for high-performance microbial fuel cells. Journal of Power Sources, 258:204-209, 2014.

[8] P.R. Shearing, L.E. Howard, P.S. Jørgensen, N.P. Brandon, and S.J. Harris. Characterization of the 3-dimensional microstructure of a 
graphite negative electrode from a Li-ion battery. Electrochemistry Communications, 12(3):374-377, 2010.

[9] V. Yu, P. Shearing, R.W. Hamilton, P.D. Lee, M. Wu, and N.P. Brandon. Investigation of lithium-ion polymer battery cell failure using X-ray computed tomography. Electrochemistry Communications, 13:608-610, 2011.

[10] P.R. Shearing, Q. Cai, J.I. Golbert, V. Yufit, C.S. Adjiman, and N.P. Brandon. Microstructural analysis of a solid oxide fuel cell anode using focused ion beam techniques coupled with electrochemical simulation. Journal of Power Sources, 195(15):4804-4810, 2010.

[11] S.J. Cooper, D.S. Eastwood, J. Gelb, G. Damblanc, D.J.L. Brett, R.S. Bradley, P.J. Withers, P.D. Lee, A.J. Marquis, N.P. Brandon, and P.R. Shearing. Image based modelling of microstructural heterogeneity in LiFePO 4 electrodes for Li-ion batteries. Journal of Power Sources, 247:1033-1039, 2014.

[12] V. Vanpeene, J. Villanova, J.P. Suuronen, A. King, A. Bonnin, J. Adrien, E. Maire, and L. Roué. Nano Energy Monitoring the morphological changes of Si-based electrodes by X-ray computed tomography : A 4D-multiscale approach. Nano Energy, 74, 2020.

470

[13] Jens Eller, Tomas Rosén, Federica Marone, Marco Stampanoni, Alexander Wokaun, and Felix N. Büchi. Progress in In Situ X-Ray Tomographic Microscopy of Liquid Water in Gas Diffusion Layers of PEFC. Journal ofThe Electrochemical Society, 158(8):963-970, 2011. 
[14] Iryna V Zenyuk, Dilworth Y Parkinson, Liam G Connolly, and Adam Z Weber. Gas-diffusion-layer structural properties under compression via X-ray tomography. Journal of Power Sources, 328:364-376, 2016.

[15] Emily Leonard, Andrew D. Shum, Nemanja Danilovic, Christopher Capuano, Katherine E. Ayers, Lalit M. Pant, Adam Z. Weber, Xianghui Xiao, Dilworth Y Parkinson, and Iryna V. Zenyuk. Interfacial analysis of a PEM electrolyzer using X-ray computed tomography. Sustainable Energy $\&$ Fuels, 4(2), 2019.

[16] Johannes Landesfeind, Martin Ebner, Askin Eldiven, Vanessa Wood, and Hubert A Gasteiger. Tortuosity of Battery Electrodes : Validation of Impedance-Derived Values and Critical Comparison with 3D Tomography Tortuosity of Battery Electrodes : Validation of Impedance-Derived Values and Critical Comparison with 3D Tomography. Journal of the Electrochemical Society, 165(3):A469-A476, 2018.

[17] Johannes Landesfeind, Johannes Hattendorff, Andreas Ehrl, Wolfgang A Wall, and Hubert A Gasteiger. Tortuosity Determination of Battery Electrodes and Separators by Impedance Spectroscopy Tortuosity Determination of Battery Electrodes and Separators by Impedance Spectroscopy. Journal of The Electrochemical Society, 163(7):A1373-A1387, 2016.

[18] Igor Mele, Ivo Pačnik, Klemen Zelič, Jože Moškon, and Tomaž Katrašnik. Advanced Porous Electrode Modelling Framework Based on More Consistent Virtual Representation of the Electrode Topology Advanced Porous Electrode Modelling Framework Based on More Consis- 
tent Virtual Representation of the Electrode Topology. Journal of the Electrochemical Society, 167(060531), 2020.

500

[19] R. de Levie. On porous electrodes in electrolyte solutions*. Electrochimica Acta, 8:751-780, 1963.

[20] Masayuki Itagaki, Satoshi Suzuki, Isao Shitanda, and Kunihiro Watanabe. Electrochemical Impedance and Complex Capacitance to Interpret Electrochemical Capacitor. Electrochemistry, 75(8):649-655, 2007.

[21] Masayuki Itagaki, Yasunari Hatada, Isao Shitanda, and Kunihiro Watanabe. Complex impedance spectra of porous electrode with fractal structure. Electrochimica Acta, 55:6255-6262, 2010.

[22] Uwe Tröltzsch and Olfa Kanoun. Generalization of transmission line models for deriving the impedance of diffusion and porous media. Electrochimica Acta, 75:347-356, 2012.

[23] Jong H. Jang, Songhun Yoon, Bok. H. Ka, Yong-Ho Jung, and Seung M. Oh. Complex Capacitance Analysis on Leakage Current Appearing in Electric Double-layer Capacitor Carbon Electrode. Journal of the Electrochemical Society, 152(7):A1418-A1422, 2005.

[24] Nobuhiro Ogihara, J Electrochem Soc, Nobuhiro Ogihara, Shigehiro Kawauchi, Chikaaki Okuda, Yuichi Itou, and Yoji Takeuchi. Theoretical and Experimental Analysis of Porous Electrodes for Lithium- Ion Batteries by Electrochemical Impedance Spectroscopy Using a Symmetric Cell Theoretical and Experimental Analysis of Porous Electrodes for 
[29] T. Hildebrand and P. Ru. A new method for the model-independent assessment of thickness in three-dimensional images. Journal of $\mathrm{Mi}$ croscopy, 185(1):67-75, 1997.

[30] J. Middaugh, S. Cheng, and W. Liu. How to Make Cathodes with a

[31] P. Aelterman, S. Freguia, J. Keller, W. Verstraete, and K. Rabaey. The 
anode potential regulates bacterial activity in microbial fuel cells. Applied Microbiology and Biotechnology, 78(3):409-418, 2008.

[32] Mark E Orazem, Nadine Pébère, and Bernard Tribollet. Enhanced Graphical Representation of Electrochemical Impedance Data. Journal of The Electrochemical Society, 153(4):B129-B136, 2006.

[33] G.J. Brug, A.L.G. van den Eeden, M. Sluyters-Rehbach, and J.H. Sluyters. The analysis of electrode impedance complicated by the presence of a constant phase element. Journal of Electroanalytical Chemistry, 176:275-295, 1984.

[34] Mark E. Orazem, Isabelle Frateur, Bernard Tribollet, Vincent Vivier, Sabrina Marcelin, Nadine Pébère, Annette L. Bunge, Erick A. White, Douglas P. Riemer, and Marco Musiani. Dielectric Properties of Materials Showing Constant-Phase-Element ( CPE ) Impedance Response Dielectric Properties of Materials Showing Constant-Phase-Element ( CPE ) Impedance Response. Journal of the Electrochemical Society, 160(6):C215-C225, 2013.

[35] M. Oliot, S. Galier, H. Roux De Balmann, and A. Bergel. Ion transport in microbial fuel cells: key roles, theory and critical review. Applied Energy, 183:1682-1704, 2016. 


\begin{tabular}{|c|c|c|c|c|c|c|c|c|c|}
\hline & $\begin{array}{l}24 \mathrm{~h}(\mathrm{ac}- \\
\text { tivated } \\
\text { sludge } \\
1)\end{array}$ & $\begin{array}{l}72 \mathrm{~h}(\mathrm{ac}- \\
\text { tivated } \\
\text { sludge } \\
1)\end{array}$ & $\begin{array}{l}\text { (acti- } \\
\text { vated } \\
\text { sludge } \\
1 \text { ) }\end{array}$ & $\begin{array}{l}24 \mathrm{~h}(\mathrm{ac}- \\
\text { tivated } \\
\text { sludge } \\
2)\end{array}$ & $\begin{array}{l}72 \mathrm{~h}(\mathrm{ac}- \\
\text { tivated } \\
\text { sludge } \\
2)\end{array}$ & $\begin{array}{l}120 \mathrm{~h} \\
\text { (acti- } \\
\text { vated } \\
\text { sludge } \\
2)\end{array}$ & $\begin{array}{l}24 \mathrm{~h} \\
\text { (syn- } \\
\text { thetic } \\
\text { medium) }\end{array}$ & $\begin{array}{l}72 \mathrm{~h} \\
\text { (syn- } \\
\text { thetic } \\
\text { medium) }\end{array}$ & $\begin{array}{l}120 \mathrm{~h} \\
\text { (syn- } \\
\text { thetic } \\
\text { medium) }\end{array}$ \\
\hline & $\begin{array}{ll}20,3 \quad \pm \\
0,2 & \end{array}$ & $\begin{array}{l}17,8 \quad \pm \\
0,4\end{array}$ & $\begin{array}{l}19,1 \quad \pm \\
0,2\end{array}$ & $\begin{array}{ll}20,5 \quad \pm \\
0,2 & \end{array}$ & $\begin{array}{ll}21,4 \quad \pm \\
0,4\end{array}$ & $\begin{array}{ll}23,4 \quad \pm \\
0,3\end{array}$ & $\begin{array}{ll}8,8 & \pm \\
0,4 & \end{array}$ & $\begin{array}{ll}8,9 & \pm \\
0,2 & \end{array}$ & $\begin{array}{ll}9,8 & \pm \\
0,5 & \end{array}$ \\
\hline $\begin{array}{l}R_{i o r} \\
(\Omega .\end{array}$ & $\begin{array}{ll}9,9 \quad \pm \\
0,8 & \end{array}$ & $\begin{array}{ll}10,0 \quad \pm \\
1,2\end{array}$ & $\begin{array}{ll}14,8 \quad \pm \\
0,9 & \end{array}$ & $\begin{array}{ll}11,8 \quad \pm \\
1,0\end{array}$ & $\begin{array}{l}30,0 \quad \pm \\
2,2\end{array}$ & $\begin{array}{ll}32,0 \quad \pm \\
3,2 & \end{array}$ & $\begin{array}{ll}6,0 \quad \pm \\
0,6 & \end{array}$ & $\begin{array}{ll}3,5 \quad \pm \\
0,9 & \end{array}$ & $\begin{array}{ll}1,6 \quad \pm \\
0,2 & \end{array}$ \\
\hline $\begin{array}{l}R_{c t, A} \\
\left(\Omega . c m^{2}\right)\end{array}$ & $\begin{array}{l}13055 \\
\text { unde- } \\
\text { fined }\end{array}$ & $\begin{array}{l}694 \quad \pm \\
22\end{array}$ & \pm 5 & \pm 2 & \pm 8 & $44+8$ & $\begin{array}{l}1,3.10^{7} \\
\text { unde- } \\
\text { fined }\end{array}$ & $\begin{array}{l}3,3 \quad \pm \\
0,4\end{array}$ & $\begin{array}{l}2,5 \quad \pm \\
0,3\end{array}$ \\
\hline $\begin{array}{l}Q_{d l, A} \\
\left(F . s^{\alpha-1} . \mathrm{cm}^{-2}\right)\end{array}$ & $\begin{array}{l}0,038 \pm \\
0,012\end{array}$ & $\begin{array}{l}0,052 \pm \\
0,002\end{array}$ & $\begin{array}{l}0,075 \pm \\
0,010\end{array}$ & $\begin{array}{l}0,062 \pm \\
0,005\end{array}$ & $\begin{array}{l}0,078 \pm \\
0,011\end{array}$ & $\begin{array}{l}0,089 \pm \\
0,014\end{array}$ & $\begin{array}{l}0,052 \pm \\
0,008\end{array}$ & $\begin{array}{l}0,146 \pm \\
0,007\end{array}$ & $\begin{array}{l}0,130 \pm \\
0,014\end{array}$ \\
\hline$\alpha$ & $\begin{array}{ll}0,65 \quad \pm \\
0,04\end{array}$ & $\begin{array}{ll}0,72 \quad \pm \\
0,01 & \end{array}$ & $\begin{array}{ll}0,70 \quad \pm \\
0,02 & \end{array}$ & $\begin{array}{ll}0,62 \quad \pm \\
0,03 & \end{array}$ & $\begin{array}{ll}0,75 \quad \pm \\
0,02 & \end{array}$ & $\begin{array}{ll}0,75 & \pm \\
0,03 & \\
\end{array}$ & $\begin{array}{ll}0,82 \quad \pm \\
0,01 & \\
\end{array}$ & $\begin{array}{ll}0,71 \quad \pm \\
0,02 & \\
\end{array}$ & $\begin{array}{ll}0,60 \quad \pm \\
0,05 & \end{array}$ \\
\hline $\begin{array}{l}C_{d l, A} \\
\left(m F . \mathrm{cm}^{-2}\right)\end{array}$ & $\begin{array}{l}2,09 \quad \pm \\
0,10\end{array}$ & $\begin{array}{l}7,03 \quad \pm \\
0,09\end{array}$ & $\begin{array}{ll}7,07 \quad \pm \\
0,05 & \end{array}$ & $\begin{array}{ll}2,43 & \pm \\
0,07 & \end{array}$ & $\begin{array}{l}1,19 \pm \\
0,05\end{array}$ & $\begin{array}{l}13,42 \pm \\
0,10\end{array}$ & $\begin{array}{l}19,09 \pm \\
0,07\end{array}$ & $\begin{array}{l}30,81 \pm \\
0,08\end{array}$ & $\begin{array}{l}36,09 \pm \\
0,11\end{array}$ \\
\hline & $\begin{array}{l}1 \text { unde- } \\
\text { fined }\end{array}$ & $\begin{array}{l}1 \text { unde- } \\
\text { fined }\end{array}$ & $\begin{array}{l}1 \text { unde- } \\
\text { fined }\end{array}$ & $\begin{array}{l}1 \text { unde- } \\
\text { fined }\end{array}$ & $\begin{array}{l}1 \text { unde- } \\
\text { fined }\end{array}$ & $\begin{array}{l}1 \text { unde- } \\
\text { fined }\end{array}$ & $\begin{array}{l}1 \text { unde- } \\
\text { fined }\end{array}$ & $\begin{array}{l}1 \text { unde- } \\
\text { fined }\end{array}$ & $\begin{array}{l}1 \text { unde- } \\
\text { fined }\end{array}$ \\
\hline & $\begin{array}{ll}11 & \pm \\
01 & \end{array}$ & $\begin{array}{ll}0,11 \quad \pm \\
0,02 & \end{array}$ & $\begin{array}{l}0,13 \pm \\
0,01\end{array}$ & $0,10 \pm$ & $\begin{array}{ll}0,12 \quad \pm \\
0,04\end{array}$ & $\begin{array}{ll}0,12 \quad \pm \\
0,05 & \\
\end{array}$ & $\begin{array}{ll}0,10 \quad \pm \\
0,01 & \\
\end{array}$ & $\begin{array}{ll}0,11 \quad \pm \\
0,01 & \\
\end{array}$ & $\begin{array}{ll}0,10 \quad \pm \\
0,02\end{array}$ \\
\hline & $\begin{array}{l}20788 \\
\text { unde- } \\
\text { fined }\end{array}$ & $\begin{array}{l}1395 \quad \pm \\
22\end{array}$ & $204 \pm 5$ & $6 \pm 2$ & $220 \pm 8$ & $211 \pm 8$ & $\begin{array}{l}2,4.10^{7} \\
\text { unde- } \\
\text { fined } \pm \\
5\end{array}$ & $\begin{array}{l}5,3 \quad \pm \\
0,5\end{array}$ & $\begin{array}{ll}4,7 & \pm \\
0,5 & \end{array}$ \\
\hline ) & $1,31 \quad \pm$ & $\begin{array}{ll}4,41 \quad \pm \\
0,10\end{array}$ & $\begin{array}{ll}4,44 \quad \pm \\
0,06\end{array}$ & $\begin{array}{l}, 53^{31} \\
, 08\end{array}$ & $\begin{array}{ll}9,08 \quad \pm \\
0,08 & \end{array}$ & $\begin{array}{l}10,71 \pm \\
0,13\end{array}$ & $\begin{array}{l}14,31 \pm \\
0,08\end{array}$ & $\begin{array}{l}19,42 \pm \\
0,11\end{array}$ & $\begin{array}{l}19,33 \pm \\
0,12\end{array}$ \\
\hline
\end{tabular}

Table 2: Electrochemical parameters and their deviation determined by fitting the impedance spectra obtained at $-0.2 \mathrm{~V}$ vs $\mathrm{Ag} / \mathrm{AgCL}$ as a function of time and medium. 